\title{
Olympian Performance: The Cultural Economics of the Opening Ceremony of
} London 2012

Michael McKinnie

\section{[PLACE FIGURE 1 HERE]}

Figure 1 Caption: "Second to the Right and Straight on Till Morning," Isles of Wonder. Opening Ceremony, London 2012 Summer Olympics. Photo: Cameron Spencer/Getty Images Sport/Getty Images

\section{Introduction}

The 2012 Olympic Games commenced in London in spectacular fashion, with a three-and-a-half hour opening ceremony staged by Danny Boyle, the theatre and cinema director best known for his Academy Award-winning film, Slumdog Millionaire. The ceremony's set-piece show, Isles of Wonder, was performed by a professional and community cast of over 7500 in the newly-built, 80,000 seat Olympic Stadium in the city's east end. ${ }^{1}$ Budgeted at a cost of approximately $£ 27$ million and lasting about ninety minutes, the show offered a succession of extravagantly staged scenes depicting different moments in British history, densely packed with references to British historical events and cultural figures (from the Industrial Revolution to the founding of the National Health Service to the creation of the World Wide Web, and from William Shakespeare to Harry Potter author J.K. Rowling to Mr. Bean, among others). As a performance event alone, Isles of Wonder was a hugely impressive undertaking, not only in terms of the inventiveness and scale of its staging but also in terms of the sheer amount of organizational skill involved in bringing it off. 
In the United Kingdom, media commentators almost universally applauded Isles of Wonder, regardless of their own political leanings or those of the outlets in which their work appeared. ${ }^{8}$ Thus, it was entirely apt to lead the piece with a major scene entitled, "Green and Pleasant Land," accompanied by the familiar music to which Sir Hubert Parry set Blake's poem, "Jerusalem." Although the poem (and the longer, separate work that goes by the same name) is a significant example of English radical romanticism, Parry's popular musical adaptation has historically been associated with very different types of political projects and institutions in Britain: the poem was originally set to music during World War I in the hope of boosting national morale; it was adopted by the suffragist movement; it is the anthem of the Women's Institute; Clement Atlee used its final verse as a campaign slogan during Labour's successful election campaign in 1945 and it is still sung regularly at Labour Party conferences (but it has also been sung at Conservative Party conferences); every year it concludes the Last Night of The Proms, which features a program of patriotic orchestral music; and it was sung at the wedding of Prince William and Kate Middleton in 2011. ${ }^{9}$ The extent of the affirmative political consensus surrounding the opening ceremony was illustrated most clearly when a Conservative Member of Parliament, Aidan Burley, tweeted that Isles of Wonder was "leftie multi-cultural crap": his comments were swiftly disavowed by Number 10 Downing Street, the office of Conservative Prime Minster David Cameron. ${ }^{10}$

Commentators employed one word, more than any other, to describe Isles of Wonder: "bonkers." Without wishing to elide the use of a problematic euphemism for mental illness here, the term nonetheless reveals rather more about the cultural politics of the opening ceremony than simply pointing to the (ostensibly very British) eccentricity of the performance. The sense that Isles of Wonder was "bonkers" (or its 
corollaries--that it was "insane" or "deeply odd") was produced through the interplay of at least several elements of the performance: an especial density of cultural selfreferentiality; a repeated interpolation of elite and mass cultural artefacts and practices; a mixing of historical periods and artistic genres; and a deployment of a very broad tonal spectrum, from the reverential to the silly to the fantastic. Weaving all of these elements into a ninety-minute narrative also meant that, dramaturgically, Isles of Wonder was necessarily a great deal more experimental than its populism implied, with the result that watching it was a more disorienting--if pleasurable-experience than might usually be expected of an Olympics opening ceremony.

This interplay was not, however, wholly theatrical in nature. Watching Isles of Wonder in the United Kingdom in 2012, it was notable how the performance, and the Olympics more broadly, played out against the program of economic austerity imposed by the Conservative-Liberal Democrat government of the time. These political-economic conditions invite a rather more expansive reading of the response to Isles of Wonder than might first appear to be the case. The oddness that commentators identified was very apparent, but was not simply restricted to what might be characterized as the theatrical elements of the entire performance event; it was also the result of an uneasy interplay between those elements and the Olympic infrastructure that the performance put on display at the same time.

In this article, then, I consider Isles of Wonder as both a theatrical and economic event. The show, as a theatrical performance and a performance of Olympic infrastructure, staged two models of political economy simultaneously: a theatrically Keynesian one and an infrastructurally rentier one. The delirium associated with the performance--what made it seem bonkers--resulted from watching this interplay happen. On the one hand, Isles of Wonder contained, at its heart, a 
stirring theatrical tribute to social welfare, and, through its coordination of a huge cast of performers drawn from a wide spectrum of British society, appeared to be a theatrical metonym of Keynesian forms of public investment and productivity. This was all the more appealing due to the fact that Keynesianism had largely been abandoned in the coalition government's embrace of austerity economics. On the other hand, Isles of Wonder highlighted infrastructure (the Olympic Stadium, and the Olympics' building estate as a whole) that was a travesty of that Keynesianism. The Keynesian rationale for public investment in fixed assets is, at least in principle, to improve the productivity of the economy generally rather than to enrich particular producers. The London Olympics, however, entailed large amounts of public investment in fixed assets and the subsequent transfer of those assets, at relatively low prices, to monopoly (or near monopoly) control by private companies. The costs and risks of this investment were therefore largely borne by the public purse, but the profits (or rents) were ultimately intended to accrue to the private sector. The opening ceremony was "bonkers," then, not only because of its spectacular theatricality but also because of its spectacular economics, and the uncomfortable ability of performance to keep both in play but resolve neither.

\section{Theatrical Keynesianism}

Owing to its heavy reliance on finance industries, the UK was hit hard by the 2008 economic crisis, which nearly ruined the country's banking system and required massive state intervention in order to prop up the country's key economic institutions (former Labour Chancellor of the Exchequer Alistair Darling subsequently observed that the cash machines of Britain had been hours away from running out of money). ${ }^{11}$ The 2010 national election produced a hung parliament that led to a coalition 
government comprised of Conservatives and Liberal Democrats, and in its first budget the new government took a sharp turn toward austerity, with Chancellor George Osborne introducing measures that acutely constrained public spending and projected huge further cuts for years to come. The effect of Osborne's austerity regime was to push the British economy into another recession in 2011-12.

Furthermore, huge parts of the public sector were subjected to wholesale restructuring, most notably the National Health Service, which was put through a vast array of market-oriented reforms (after the Tories had promised no "top-down reorganisation of the NHS)."12

It is against this political-economic backdrop that Isles of Wonder played out. The show was organized into seven main scenes. ${ }^{2}$ The first, "Green and Pleasant Land," depicted an agrarian, pre-modern Britain prior to the arrival of the Industrial Revolution. ${ }^{3}$ The second, "Pandemonium," portrayed the onset of industrialization, opening with famed engineer Isambard Kingdom Brunel (played by actor Kenneth Branagh) speaking Caliban's "Be not afeard" speech from Shakespeare's The Tempest. This portrayed Britain's socio-economic development from the Industrial Revolution to the 1960s. At the end of "Pandemonium" workers "forged" the five Olympic rings and these were lifted into place above the stadium (a picture of the fiery rings was the most commonly used image on the front pages of the following day's newspapers in Britain). ${ }^{4}$ The next scene, "Happy and Glorious," introduced the Queen, as Head of State, through a combination of film and live performance. ${ }^{5}$ This involved one of the key jokes in the ceremony, where James Bond (played by the current Bond actor, Daniel Craig) and the Queen (played by Elizabeth II herself) ostensibly parachuted into the Olympic stadium, after which the Queen was then revealed, with the rest of her party, in her royal box. Following a rendition of God Save the Queen by a choir 
of deaf children, "Second to the Right, and Straight on Till Morning" celebrated the founding of the National Health Service in 1948 as well as children's literature in Britain. ${ }^{6}$ This was followed by "Interlude," which honoured British cinema (and included a jokey appearance by Rowan Atkinson as Mr. Bean), and "Frankie and June Say...Thanks Tim," which celebrated British popular music and culture (and featured Tim Berners Lee, the British inventor of the World Wide Web). The show closed with "Abide With Me," a tribute to those who could not be present in the stadium that night, including those who died in the London bombings of July $7,2005 .^{7}$

In the UK, one part of Isles of Wonder attracted particular attention: the tribute to Great Ormond Street Hospital, the National Health Service, and children's literature contained within "Second to the Right, and Straight on Till Morning."13 Great Ormond Street — the country's oldest and most prominent children's hospital, to which J.M. Barrie left the future royalties from Peter Pan upon his death—provided a canny way to bridge the National Health Service with children's literature. As the scene's performers entered, many of whom worked in the NHS, an announcement was made in the Olympic Stadium: "Please welcome Mike Oldfield [the musician played live during the scene] and the staff of the United Kingdom National Health Service, and our very special guests this evening, patients and staff of Great Ormond Street Hospital." Hundreds of performers costumed as hospital staff arranged beds, each carrying a child "patient," in the shape of the logo of the Great Ormond Street Hospital Charity (a line drawing of a child's smiling but also tear-streaked face) underscored by the letters "GOSH." As the electric pulse of a cardiac monitor raced around the seating banks of the darkened stadium the completed GOSH image was picked out in light. Nurses then joined the children in their beds and began to read to them. Within moments, "Tubular Bells" gave way to raucous swing music and the 
children jumped up and down on their beds (their "mattresses" were, in fact, trampolines) and the hospital staff swing-danced, with each other and en masse, around the enormous playing area, while also miming duties such as giving injections and washing their hands. Simultaneously other cast members formed a new image in the centre of the stadium: three giant letters spelling out the current logo of the NHS, lit in brilliant white. The cast continued to dance until the swing music gave way to a lullaby, whereupon the staff tucked the children into bed, hushing them to sleep. The children, however, continued to read under their sheets, flashlights in hand, while JK Rowling appeared and recited a passage from Peter Pan: "Of all delectable islands, Neverland is the snuggest. It's not large and sprawly--you know, with boring distances between one adventure and the next. It's nicely crammed. When you play at it by day, with the table and chairs, it's not a bit frightening. But in the two minutes before you go to sleep it is real." Monsters swooped around the children in their beds, led by the Child Catcher from Chitty Chitty Bang Bang, and giant puppets of villains from children's literature, including Cruella de Vil, Lord Voldemort, Captain Hook, and the Queen of Hearts, rose over the frightened patients. An army of Mary Poppinses then "flew" in from high in the stadium, umbrellas open, and attacked the "baddies," cheered on by the children and hospital staff. With the monsters chased away, the Mary Poppinses joined the children and staff in a further dance, before the children were tucked safely into bed. The scene concluded with a huge image of a baby's head, an undulating bedsheet indicating its body, to celebrate Scottish physician Ian Donald's pioneering work in developing obstetrical imaging technology at the University of Glasgow in the 1950s.

Seen in the wider context of austerity, and given the currency of the government's controversial restructuring of the NHS, it is not surprising that this 
scene had particular resonance. "Second to the Right, and Straight on Till Morning" celebrated a key welfare state institution and the public values that underpinned it, but if this tribute seemed at odds with the coalition government's economic policies the scene's dramaturgy cleverly forestalled ideological antagonism toward the NHS. The scene explicitly referenced the fact that the NHS was established in the same year1948 — that London last hosted the Olympic Games. Like 2012, 1948 was a time of economic austerity, but, as Isles of Wonder highlighted, it was one that prompted the creation of new forms of social welfare rather than one that imposed austerity as a pretext for their weakening. The scene also diachronically posited a historical continuity between the NHS of 1948 and 2012 by incorporating signs from both eras: the hospital staff were dressed in uniforms from the 1940s, but the NHS emblem they formed was its 2012 logo. The centrality of children, not only in this scene but in the ones immediately preceding it and following it, put an optimistic gloss on who the NHS exists to serve; in contrast to recurring media and political controversies over drunks ostensibly clogging up Accident and Emergency wards to the detriment of the hard-working taxpayer, the scene proposed that the NHS is all about the kids. The choreography of "Second to the Right, and Straight on Till Morning" also suggested a high-minded continuum between theatrical pleasure and a unifying social citizenship, both for those characters within the conflict-free NHS depicted and for the spectators whose own enjoyment of the scene signalled their membership of a broader commons.

Through its social form, the scene also looked remarkably like a theatrical version of Keynesian productivity that austerity economics seeks to disavow. As a display of tightly organized theatrical production, "Second to the Right, and Straight on Till Morning" (along with Isles of Wonder as a whole) looked as economically impressive as it did artistically: it coordinated a huge cast containing "professional" 
and "amateur" performers with great skill and, in doing so, successfully created both a "good" (in an economic sense) and a "good" (in a social sense). In short, it offered an affective hypothesis of what an economy based on mutuality and productivity might look and feel like.

\section{Rentier Performance}

At the time of the Olympics the British economy had been in recession for much of the previous year, and the political desire for the Games to provide an economic boost was intense. Since the Barcelona Olympics in 1992, the dominant rationale advanced for hosting the Olympic Games has been an infrastructural one. The massive public spending that the Olympics usually involve can be used, the argument goes, to generate significant improvements to the urban infrastructure of the host city, whether to its transportation systems, its housing stock, its urban environment, and more. This argument has the advantage of being palatable to both the political Left and Right, though for different reasons: for the Left, the Olympics are a way to leverage public investment in infrastructure to a degree that might otherwise be politically difficult to accomplish (this was the basis on which former London mayor Ken Livingstone, previously a skeptic of London's Olympic ambitions, supported the bid to host the Games in the first place); for the Right, the prestige of the Olympics provides political cover for types of public spending that it might otherwise be reluctant to accept (indeed, the Olympics are arguably one of the few remaining areas in political discourse where conservative politicians actively support public spending on the apparently old-fashioned basis of its benefit to the wider economy). 
The economic benefits of the Games, though, are thought by many economists to be negligible, at best: they involve already anticipated spending, not new spending; although the headline investment figure is large, it is spread over too long a period to have much effect on overall economic growth; and it arguably involves a less-thanideal allocation of public resources — governments wind up spending a lot of money on things they otherwise wouldn't, while paying top price for them. An Olympic Games may result in improvements to, say, a city's transport system, but this is usually bought at the expense of a number of very costly white elephants. The argument that the Olympics produce economic benefits should be treated warily, as it often effaces significant fiscal and social costs that the Olympics inevitably entail, and most economists agree that hosting the Olympics should not be justified to any significant degree on an economic basis. ${ }^{14}$

However doubtful the merits of the investment, the Olympics nonetheless commonly result in a large stock of built infrastructure, and London was no different in this regard. Olympic investment produced a new stadium, thousands of units of housing, improvements to the transportation network of east London, amenities such as the Olympic Park, and a whole host of sporting facilities. Many of these are what economists call "fixed assets," which are most commonly property, buildings and equipment. ${ }^{15}$ The construction of fixed assets is key to ensuring the long-term viability of economic production and an important show of confidence in the future prospects of the economy. As Keynes observes, it is through their existence that "the economic future is linked with the present." ${ }^{16}$

In his landmark General Theory of Employment, Interest and Money (1936), Keynes asks why investments in fixed assets happen and what their construction signifies more broadly. He explains the first part of this question through his theory 
of the "marginal efficiency of capital." ${ }^{17}$ Keynes argues that the marginal efficiency of capital is determined by yield (the value of goods produced less input costs and maintenance costs of the asset producing those goods) minus supply cost (the prospective cost of creating another, say, machine or factory to produce those goods instead of the assets the producer already possesses). Producers will invest in fixed assets if they expect that the marginal efficiency of capital will be greater in the future than it is today (and the reverse is also true--if producers anticipate that yields will be lower in the future then they are likely to hoard capital, use up any spare capacity, and wait until they perceive conditions are improving). Thus deciding whether or not to invest in fixed assets is a calculation based not on existing conditions but confidence in future, anticipated conditions. The problem, though, is that the former are much more reliably assessed than the latter--current conditions actually exist, whereas future conditions have to be projected, often disproportionately based on what is already known. As Keynes observes, "The outstanding fact is the extreme precariousness of the basis of knowledge on which our estimates of prospective yield have to be made," something that encourages investors to adopt short-term and riskdisplacing approaches. ${ }^{18}$ Public investment in fixed assets is therefore a hugely important corrective, since it can employ a calculus of yield that is both temporally and socially more expansive than the market is likely to entertain. As a result, London's Olympic facilities, as fixed assets built through public investment, appeared to demonstrate exactly the sort of confidence in the future that is publicly needed at a time of profound economic uncertainty. Literally and figuratively, London's Olympic infrastructure purported to made the link between today and a better tomorrow concrete. 
The difficulty, though, is that this economic performance did not entirely convince in terms of its market or social value, due to the particularly Olympian character of the infrastructure involved. First, realizing any market-based yield through Olympic facilities is very challenging, since many of these assets cannot be monetized to any significant degree (it is hard to imagine a velodrome turning a profit, for example). The anxious question which Olympics facilities prompt is less, "will there be white elephants?" and more, "how many white elephants will there be?"19 The long history of Olympic facilities is, to a significant degree, a history of trying-and often failing--to escape the white elephant problem. Montreal's Olympic Stadium is perhaps the best known, and most extreme, example of an Olympic white elephant, but Beijing's iconic "Bird's Nest" stadium is now idle much of the year, and Athens' Olympic Stadium sits empty (along with many of the city's other Olympic facilities, which were largely abandoned after the collapse of Greece's economy following the credit crisis). Tokyo, which will host the 2020 Olympics, is scrambling to cut the cost of its proposed stadium and cancelled plans for a Zaha Hadid-designed stadium after its budget spiralled (leading to a public apology from the government). If, as Marvin Carlson points out, the place of performance is a "haunted house," a kind of "memory machine" that not only evokes cultural memories but, through its built form, is an especially concentrated materialization of those historical associations, these "ghostings" are not only theatrical in nature. Olympic stadiums may host theatrical performances such as Isles of Wonder but they are also imbued with a lineage of Olympic white elephants. The theatrical element of the Olympian performance cannot wholly displace the economic genealogy that the stadium embodies.

Even if it were possible to realize a market-based yield, this is often only through additional public investment, on top of already substantial expenditure, and 
subsequent transfer of the asset to the private sector at little or no cost to it. However impressive Isles of Wonder might have been at the time, and however striking it made the Olympic Stadium look, the fact could not be completely deferred that its future life, as the home of West Ham United Football Club, would entail a further, publicly-financed, and very expensive remodelling on the club's behalf (and it is no accident that the post-Games tenancy of the Olympic Stadium was subject to much litigation by competing football clubs--it is rare that such an asset becomes available at so little cost). In keeping with the cost over-runs that marked the London Olympics (and which mark Olympic Games generally), the Olympic Stadium was originally budgeted at $£ 280$ million but its final cost came in at $£ 429$ million. At least some of these additional costs were due to changes to the stadium's design, from its original conception as a temporary athletics venue to its final configuration as a multipurpose sports arena that could have a "legacy use" once the Games were over (which, in practice, meant primarily as a football stadium). The resulting stadium was still unsuitable for football, however, and soon after the Games finished large sections of it were removed and it was effectively rebuilt within the original shell, at a cost of an additional $£ 272$ million, for use by West Ham United. The vast majority of these conversion costs came from public funds, with the largest subventions coming from the national Treasury (a grant of approximately $£ 150$ million) and Newham Borough Council, in which the stadium is located (a $£ 40$ million loan). Newham, it should be noted, is one of the poorest local authorities, not only in London, but in the United Kingdom as well. West Ham United paid only $£ 15$ million towards the refurbishment and it is thought that the club will pay about $£ 2.5$ million a year in rent on a 99 -year lease, though this figure has never been publicly confirmed..$^{20}$ As with many agreements between public bodies and private enterprises in recent years, most of the 
terms of the contract between the London Legacy Development Corporation and West Ham United have not been disclosed because of strict commercial confidentiality clauses, so potential public liabilities or possible future costs--such as if West Ham United should end its tenancy at an early date--are not known (in autumn 2015 the Information Commissioner ruled that this information should be released but the LLDC, with West Ham United's backing, appealed the ruling). ${ }^{21}$ For a Games that traded on "legacy" more than any previous Olympic Games, the Olympic Stadium is a concrete example of what legacy now means: massive public investment to create assets that are then transferred at little cost to the private sector. If the economic lineage invoked by the Olympic stadium is one of white elephants, this cosy arrangement suggests that London's economic future is based on state-guaranteed, rentier capitalism. This is in no way out of step with the rentier logic of the Olympics as a whole (as the creation of the largest Olympic legacy project, the housing development, East Village, demonstrates) nor is it surprising given London's continued, and arguably deepening, reliance on rentier forms of finance capital, despite the events following the 2008 credit crisis. ${ }^{22}$ But it would be willfully romantic to pretend that this rentier legacy did not read in performance, however at odds with the more high-minded theatrical event that unfolded within the Olympic Stadium it might have appeared to be.

\section{Conclusion}

When the cardiac monitor traced the circumference of the Olympic Stadium at the opening of "Second to the Right, and Straight on Till Morning," it condensed the contradictions staged by Isles of Wonder in a single, arresting image. The stadium 
itself had become the monitor of the country's heartbeat, this moment implied, an unnerving proposition that the show could not wholly displace but, equally, would not be undermined by. Isles of Wonder, then, demonstrated the impressive but discomfiting ability of an Olympic performance to stage economic antagonisms without being undone by them. In fact, part of the delirious pleasure of the Isles of Wonder lay in the extent to which it made these antagonisms doubly material: as theatrical material within the live show and as an infrastructural condition of its own production. That an Olympic performance could successfully do this without careening out of control only amplified the sense that, as spectators, we were watching something "bonkers." But if this experience was queasily wondrous - and it was - it is because it was an experience that is increasingly unavailable to us outside the confines of the performance. In the real world, the economic antagonism that Isles of Wonder stages may be equally, or even more, conspicuous, but there austerity has the upper hand.

\section{Notes}

1 The opening ceremony as a whole was in three successive parts: Isles of Wonder; the athletes' procession; and a concert of different British musical acts (e.g. Arctic Monkeys and Paul McCartney).

2 With a running time of approximately one hour and fifteen minutes amid a total ceremony length of about three-and-a-half hours (including the athletes' parade and concluding musical concert) it is impossible to provide a detailed account of Isles of Wonder here. The Olympics organization has made a video of the complete ceremony (with its own commentary) freely available. See The Complete London 2012 Opening Ceremony; London 2012 Olympic 
Games (Olympic Broadcasting Services, 2012),

https://www.youtube.com/watch?v=4As0e4de-rI.

3 The title of this scene is, of course, taken from William Blake's poem, "Jerusalem":

"I will not cease from Mental Fight,/Nor shall my Sword sleep in my hand:/Till we have built Jerusalem,/In England's green \& pleasant Land." William Blake, "Jerusalem," The Complete Poems, ed. Alicia Ostriker (Harmondsworth: Penguin Classics, 1977), 494.

4 "Pandaemonium" is the name John Milton gives to the capital of Hell in Paradise Lost.

5 "Happy and glorious" is a line from "God Save the Queen," the British national anthem.

6 The title consists of the directions to Neverland that Peter gives to Wendy in J.M. Barrie's Peter Pan.

7 In the UK, "Abide With Me" is commonly sung at Remembrance Day ceremonies as well as major sporting events (such as the FA Cup football final).

8 See, for example: Charlotte Higgins, "The Olympics Opening Ceremony: My Cultural Highlight of 2012," The Guardian, December 5, 2012, accessed July 18, 2015, http://www.theguardian.com/culture/2012/dec/05/olympic-openingceremony-2012-highlight; Gordon Rayner, "London 2012: Breathtaking, Brash and Bonkers...an Utterly British Olympic Opening Ceremony," July 27, 2012, accessed July 15, 2015, http://www.telegraph.co.uk/sport/olympics/news/9433818/London-2012breathtaking-brash-and-bonkers....an-utterly-British-Olympic-openingceremony.html; "Media Reaction to London 2012 Olympic Opening Ceremony," BBC News, July 28, 2012, accessed July 10, 2015, 
http://www.bbc.com/news/uk-19025686; Tracy McVeigh and Owen Gibson, “London 2012: Danny Boyle Thrills Audiences with Inventive Olympics Opening Ceremony," The Guardian, July 28, 2012, accessed July 20, 2015, http://www.theguardian.com/sport/2012/jul/28/london-2012-boyle-olympicsopening-ceremony; "London 2012: Opening Ceremony - Reviews," The Guardian, July 29, 2012, accessed July 20, 2015, http://www.theguardian.com/sport/2012/jul/29/london-2012-openingceremony-reviews; “U.K. Media Give Olympic Opening Show Glowing Reviews," July 28, 2012, accessed July 20, 2015, http://www.cbc.ca/1.1193902. International coverage was in a similar vein, if sometimes a bit perplexed by the degree of cultural self-referentiality in the event: Sarah Lyall, “A 5-Ring Circus: Olympic Opening Is Oddly, Confidently British,” The New York Times, July 27, 2012, accessed July 20, 2015, http:/www.nytimes.com/2012/07/28/sports/olympics/in-olympicopening-ceremony-britain-asserts-its-eccentric-identity.html; "Opening Ceremony of the London Olympics: Review," The Hollywood Reporter, July 27, 2012, accessed July 20, 2015, http://www.hollywoodreporter.com/review/olympic-games-openingceremony-london-danny-boyle-355545; “'“Dazzling': World’s Press Heaps Praise On Opening Ceremony," The Huffington Post UK, July 28, 2012, accessed July 20, 2015, http://www.huffingtonpost.co.uk/2012/07/28/london2012-worlds-press-heaps-praise_n_1712665.html; “London 2012: What the World Thought of the Opening Ceremony," July 28, 2012, accessed July 20, 2015, http://www.telegraph.co.uk/sport/olympics/london2012/9434319/London-2012-What-the-world-thought-of-the-opening- 
ceremony.html; "Danny Boyle Wins the Gold," The New Yorker, July 27, 2012, accessed July 10, 2015, http://www.newyorker.com/news/sportingscene/danny-boyle-wins-the-gold-2.

9 One could also argue that the invocation of the self-evidently English "Jerusalem" in a performance of Britishness was a slippage that characterized the show as a whole. Like Great Britain itself (an entity brought into being through the union of England and Scotland in 1707) the show's "Britishness" had a notably English inflection.

10 “Aidan Burley Says 'Leftie Multi-Cultural' Tweet Misunderstood,” BBC News, July 28, 2012, accessed July 20, 2015, http://www.bbc.com/news/uk19025518. Burley had a history of controversy, having been dismissed as Parliamentary Private Secretary to the Secretary of State for Transport the year before for helping organize a Nazi-themed stag party for a friend.

11 “Alistair Darling: We Were Two Hours from the Cashpoints Running Dry," The Independent, March 18, 2011, accessed July 20, 2015, http://www.independent.co.uk/news/people/profiles/alistair-darling-we-weretwo-hours-from-the-cashpoints-running-dry-2245350.html.

12 George Eaton, "The Pre-Election Pledges That the Tories Are Trying to Wipe from the Internet," New Statesman, November 13, 2013, accessed September 11, 2015, http://www.newstatesman.com/politics/2013/11/pre-electionpledges-tories-are-trying-wipe-internet.

13 "Second to the Right, and Straight on Till Morning" runs from approximately 43.52-55.43 in the official video.

14 See, for example: Stefan Szymanski, “About Winning: The Political Economy of Awarding the World Cup and the Olympic Games," SAIS Review 31.1 (2011): 
87-97, doi:10.1353/sais.2011.0003; Evangelia Kasimati, "Economic Aspects and the Summer Olympics: A Review of Related Research," International Journal of Tourism Research 5.6 (2003): 433-44, doi:10.1002/jtr.449;

Georgios Kavetsos, “The Impact of the London Olympics Announcement on Property Prices," Urban Studies 49.7 (2012): 1453-70, doi:10.1177/0042098011415436.

15 Fixed assets are distinguished from "liquid assets," such as cash.

16 John Maynard Keynes, The General Theory of Employment, Interest and Money, vol. 7, The Collected Writings of John Maynard Keynes (London: Macmillan, 1973), 146.

17 Ibid., 7:135-146.

18 Ibid., 7:149.

19 To clarify, a "white elephant" is an asset where the costs of its creation are too great to be recuperated, or the costs of its maintenance are excessive. The term derives from a story that the King of Siam ostensibly gave white elephants to courtiers who displeased him. As the gift came from the king it could not be refused but the costs to the recipient of maintaining the animal were ruinous.

20 Owen Gibson, “Details of West Ham’s Olympic Stadium Deal Must Be Made Public," The Guardian, September 15, 2015, accessed September 15, 2015, http://www.theguardian.com/football/2015/sep/15/west-ham-details-olympicstadium-deal.

21 Information Commissioner, "Decision Notice" (London: Information Commissioner's Office, September 3, 2015), https://ico.org.uk/media/actionweve-taken/decision-notices/2015/1432468/fs 50556618.pdf. 
22 East Village is now the name for the Olympic Village, and is the new neighbourhood built in Stratford, one of the poorest parts of London. East Village has been sold as a response to London's housing shortage but it is a very particular type of response: it is housing built at public expense (the private investors initially sought to underwrite it never materialized) that has been turned over to a joint venture between British real estate advisors, Delancey, and Qatari Diar, which invests in property on behalf of the Qatari sovereign wealth fund, after a substantial write-down. The vast majority of the units are in the private sector, with market-determined (and therefore high) calculations of "affordability." East Village creates housing, no doubt, but it is as much about creating of a new private property market in east London, at public expense, as it is about providing places for people to live. One does not need to create a market in order to provide places to live, but that is politically and economically impermissible in London at this historical moment. 